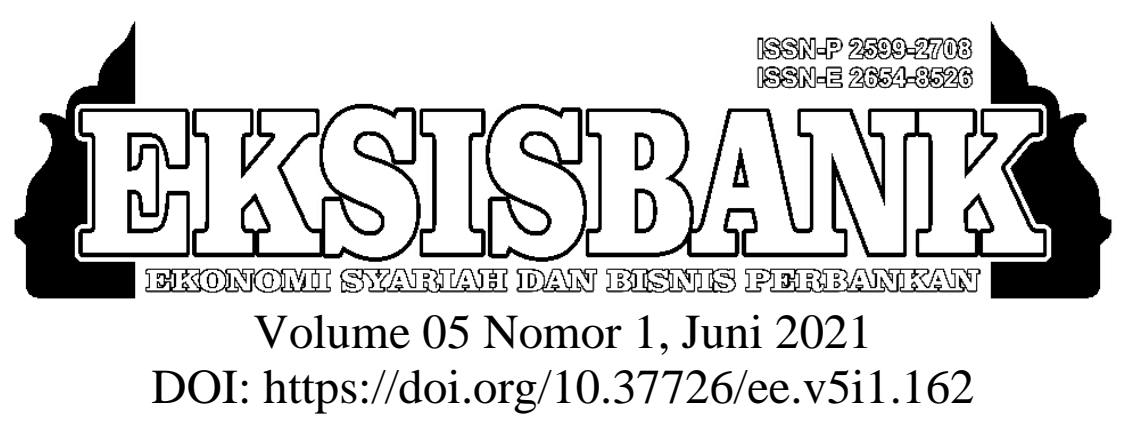

\title{
Analisis Kesehatan Bank Dengan Menggunakan Metode RGEC Pada PT. Bank Mega Syariah Tbk. Periode 2016-2019
}

\author{
Ade Ponirah $^{1}$, Faridha Nurazizah $\mathrm{Y}^{2}$, Yesa Tiara Purnama Sari ${ }^{3}$ \\ ${ }^{1,2,3}$ Magister Ekonomi Syariah, Universitas Islam Negeri Sunan Gunung Djati Bandung \\ ladeponirah@gmail.com \\ ${ }^{2}$ faridha.rahayu@gmail.com \\ 3yesatiara13@yahoo.com
}

\begin{abstract}
ABSTRAK
Tingkat kesehatan bank sangat penting untuk berbagai pihak terkait. Karena menjadi informasi sebagai bahan evaluasi kinerja sebuah bank. Bank Indonesia telah mengeluarkan aturan sebagai landasan dalam penilaian tingkat kesehatan bank. Metode yang kini banyak digunakan yaitu RGEC terdiri dari Risk Profile, Good Corporate Governance, Earnings, dan Capital. Dalam metode ini dinilai menggunakan ketentuan dan komposit yang telah ditentukan. Pada penelitian ini bertujuan untuk menganalisis tingkat kesehatan bank pada PT. Bank Mega Syariah Tbk periode 2016-2019. Pendekatan yang digunakan yaitu pendeketan deskriptif dengan data kuantitaif dari laporan tahunan yang di unduh dari web resmi. Hasil penelitian berdasarkan aspek penilaian Risk Profile bank di ukur dengan NPF termasuk dalam kaetgori sehat, lalu diukur juga dengan menggunakan FDR dalam kurun empat tahun termasuk pada kategori sehat. Pada aspek Good Corporate Governance (GCG) bank termasuk dalam komposit dua yaitu sehat. Lalu pada aspek Earnings keseluruhan selama empat tahun bank termasuk pada akategori sangat sehat. Terakhir pada aspek Capital bank termasuk pada kategori sangat sehat. Secara keseluruhan PT. Bank Mega Syariah Tbk dalam kurun waktu empat tahun berada pada nilai komposit 2 yang berarti termasuk dalam kategori sehat.
\end{abstract}

Kata kunci-Bank, Kesehatan, RGEC.

\section{ABSTRACT}

The level of health of the bank is very important for various related parties. Because it becomes information as a material evaluation of the performance of a bank. Bank Indonesia has issued rules as a basis for assessing the bank's health level. The method that is now widely used is RGEC consists of Risk Profile, Good Corporate Governance, Earnings, and Capital. In this 
method is assessed using predetermined provisions and comsits. In this study aims to analyze the level of health of banks in PT. Bank Mega Syariah Tbk for the period 2016-2019. The approach used is descriptive with quantifiable data from the annual report downloaded from the official web. The results of the study based on aspects of the bank's Risk Profile assessment measured by NPF are included in the healthy category, and then measured also by using FDR within four years included in the healthy category. In the good corporate governance (GCG) aspect, the bank is included in the composite two, namely healthy. Then on the overall Earnings aspect for four years the bank is included in the very healthy category. Then on the overall Earnings aspect for four years the bank is included in the very healthy category. Lastly on the Capital aspect the bank belongs to the very healthy category. Overall PT. Bank Mega Syariah Tbk within four years is at a composite value of 2 which means it falls into the healthy category. Keywords-Bank, Health, RGEC.

\section{PENDAHULUAN}

Perbankan merupakan salah satu alat yang berperan penting dalam lalu lintas keuangan dan ekonomi secara umum. Dikarenakan bank bertindak sebagai perantara antara orang yang mempunyai dana surplus dan orang yang membutuhkan dana. Bank merupakan sebuah insititusi yang menyediakan layananan keuangan terlengkap. Selain menghimpun dana dalam bentuk simpanan dan menyalurkan dana dalam bentuk pinjaman ataupun pembiayaan, bank juga memiliki usaha lain yang mendukung dan melancarkan kegiatan operasional bank.

Bank segaai lembaga intermediasi dan penopang berbagai aktivitas ekonomi harus memperhatikan tingkat kesehatannya. Informasi ini dibutuhkan oleh berbagai pihak baik dari pihak internal maupun pihak eksternal sebagai bahan evaluasi kerja dengan menerapkan sistem kehati-hatian. Karena masyarakat mempercayakan kepada bank untuk mengelola dananya sehingga penilaian kesehatan bank sangat penting sebagai dasar utama kepercayan masyarakat (Marimin and Romdhoni 2017).

Kesehatan bank menjadi peran penting bagi semua pihak baik pemilik, manajemen, masyarakat pengguna jasa dan pemerintah dalam hal ini Bank Indonesia sebagai otoritas pengawas perbankan, karena jika terdapat kegagalan dalam industri perbankan akan berdampak buruk terhadap perekonomian Indonesia. Kesehatan bank dapat didefinikan sebagai kemampuan bank untuk melakukan berbagai kegiatan operasional secara normal dan memenuhi semua kewajibannya dengan sesuai dengan peraturan yang berlaku (Darmawi 2011). Menurut Veitzhal Rivai kesehatan bank ialah kondisi bank yang dapat menjalankan fungsinya dengan baik, serta dapat memelihara kepercayaan masyarakat, menjalankan fungsi intermediasi, pemerintah melaksanakan berbagai kebijakan (Rivai 2007).

Untuk dapat mengetahui kesehatan bank secara keseluruhan dapat terlihat dari ciri-ciri ank tersebut apakah bank mampu melakukan kegiatan bisnis seperti biasa atau tidak. Maka diperlukannya penilaian tingkat kesehatan bank. Berdasarkan PBI No.13/1/PBI/2011 Tentang Penilaian Tingkat Kesehatan Bank secara individual dengn menggunakan risiko (Risk-based Bank Rating) meliputi empat faktor yaitu risk profile (risiko bank), good corporate govermence (GCG), eraning (rentabilitas), dan faktor capital (permodalan) di sebut dengan RGEC. Dari faktor ini akan memberikan hasil penilaia berbagai macam sisi sudut pandang pada bank syariah (Wahasusmiah and Watie 2019). 
Dari faktor-faktor yang telah di paparkan dapat dilakukan penulaian dengan cara membandingkan dengan standar atau sering disebut dengan peringkat komposit (PK) dari masing-masing rasio. Dalam peraturan Bank Indonesia terdapat lima tingkatan dalam mengukur kesehatan bank yaitu sangat sehat, sehat, cukup sehat, kurang sehat dan tidak sehat. Dari peringkat komposit ini dapat menggambarkan tingkat kesehatan bank (Paramartha and Darmayanti 2017).

Studi kasus pada penelitian ini menggunakan objek pada PT. Bank Mega Syariah, Tbk. dengan profil risiko yang digunakan risiko kredi variabel yang digunakan yaitu Non Performing Financing (NPF), risiko likuiditas menggunakan variabel Financing Deposit Ratio (DFR). Variabel yang digunakan untuk mengukur rentabilitas yaitu Return on Asset (ROA) dan Net Interest Margin (NIM), variabel yang digunakan untuk mengukur pada aspek permodalan yaitu menggunakan Capital Adequacy Ratio (CAR), selanjutnya good corporate govermence.

Permasalahan dalam penelitian ini ialah bagaimana analisis tingkat kesehatan PT. Bank Mega Syariah, Tbk dengan menggunakan metode RGEC (Risk Profile, Good Corporate Govermence, Earning, and Capital) periode 2016-2019. Tujun penelitian ini untuk menganalissi dan memahami tingkat kesehatan bank dengan menggunakan metode RGEC peridoe 2016-2019.

\section{TINJAUAN PUSTAKA}

Penelitia tentang Analisis Kesehatan Bank Dengan Menggunakan Metode RGEC Pada PT. Bank Mega Syariah Tbk. sudah banyak dilakukan oleh peneliti sebelumnya, untuk lebih jelasnya bisa dilihat pada uraian dibawah ini:
A. Analisis Tingkat Kesehatan Bank Dengan Metode RGEC Pada Bank Syariah Di Indonesia (Faryana 2020)

Penelitian ini bertujuan untuk mengetahui penilaian tingkat kesehatan bank syariah di Indonesia pada periode 2014-2018 yang ditinjau dari aspek risk profile, good corporate governance, earnings, capital dan secara keseluruhan dari aspek-aspek tersebut. Ada 10 bank syariah yang menjadi sampel penelitian ini, yaitu Bank Syariah Mandiri, Bank Panin Syariah Tbk, BNI Syariah, BRI Syariah, Bank Muamalat Indonesia, Bank Victoria Syariah, Bank Mega Syariah, Bank Syariah Bukopin, BCA Syariah dan Maybank Syariah Indonesia.

Metode pengumpulan data yang digunakan dalam penelitian ini adalah metode dokumentasi. Dalam penelitian ini, aspek Risk Profile menggunakan rasio NPF dan FDR, aspek Good Corporate Governance dilihat dari hasil self assessment bank, aspek Earnings menggunakan rasio ROA dan BOPO, dan aspek Capital menggunakan rasio CAR.

Hasil penelitian menunjukkan bahwa penilaian tingkat kesehatan secara keseluruhan menggunakan metode RGEC untuk periode 2014 Bank Panin Syariah Tbk dan BCA Syariah memperoleh peringkat komposit "sangat sehat" dan untuk periode 2015-2018 menunjukkan bahwa BCA Syariah memperoleh ranking RGEC tertinggi berada pada peringkat komposit "sangat sehat".

hasil penelitian saat ini yang membedakan dengan penelitian terdahulu yaitu tahun penelitian dimana tahun yang diteliti onel peneliti saat ini pada laporan keuangan tahun 2016-2019, selain itu lembaga penelitian yang diteliti pada penelitian terdahulu, peneliti melakukan penelitian pada lembaga perbankan syariah yang ada di Indonesia sedangkan penelitian saat ini hanya terfokus pada satu lembaga perbankan syariah. 
B. Analisis Penilaian Tingkat Kesehatan Bank Dengan Menggunakan Metode RGEC (Risk Profile, Good Corporate Governance, Earnings, And Capital) Pada Bank Umum Syariah Di Indonesia Periode 2014-2016 (Rodiyah 2019)

Penelitian ini bertujuan untuk mengetahui bagaimana kesehatan Bank Umum Syariah menggunakan metode RGEC. Teknik analisis data yang digunakan dalam penelitian ini adalah metode RGEC dan analisis laporan keuangan. Jenis penelitian deskriptif kualitatif dengan data kuantitatif. Faktor-faktor penilaian pada metode RGEC adalah: profil risiko dengan menggunakan indikator pengukuran pada faktor risiko kredit (NPF) dan risiko likuiditas (FDR), tata kelola perusahaan yang baik dengan menggunakan data yang telah diolah dan diperoleh dari masing-masing bank syariah (hasil selfassessment), earning dengan menggunakan indikator pengukuran. terhadap ROA, NIM, $\mathrm{ROE}$, dan BOPO, permodalan menggunakan indikator pengukuran CAR. Hasil penelitian ini menunjukkan bahwa bank yang memiliki status kesehatan sehat tahun 2014 sampai 2016 adalah BCASyariah dan BNI Syariah. Sedangkan bank yang berada dalam kondisi cukup sehat secara konsisten periode tahun 2014 sampai dengan tahun 2016 adalah Bank Muamalat dan Bank Victoria Syariah. Sedangkan bank lain tingkat kesehatannya cukup fluktuatif yaitu dalam keadaan sehat dan cukup sehat.

Perbedaan penelitian saat ini dengan penelitian terdahulu dapat kita lihat dari tahun penelitiannya, tempat penelitianna dimana penelitian saat ini hanya terfokus pada satu tempat lembaga perbankan syariah sedangkan penelitian terdahulu melakukan penelitian pada bank umum syariah di Indonesia.

C. Analisis Kesehatan Bank Syariah Dengan Menggunakan Metode RGEC (Risk Profile,
Governance, Earnings And Capital) Dalam Menjaga Stabilitas Kesehatan Pada PT. Bank BNI Syariah Tahun 2016 (Sa'diah and Buchor 2017)

Penelitian ini bertujuan untuk mengetahui bagaimana penerapan metode RGEC (risk profile, governance, earnings dan capital) dalam menganalisis kesehatan Bank BNI Syariah Tahun 2015 dan bagaimana analisis tingkat kesehatan dengan menggunakan metode RGEC (risk profile, governance, earnings dan capital) dalam menjaga stabilitas kesehatan Bank BNI Syariah tahun 2016. Metodologi penelitian yang digunakan adalah pendekatan kualitatif dengan jenis penelitian deskriptif. Hasil penelitian yang diperoleh adalah Berdasarkan penilaian tingkat kesehatan PT. Bank BNI Syariah tahun 2015 dengan menggunakan metode RGEC yang meliputi aspek risk profile, governance, earnings dan capital, didapatkan hasil bahwa kesehatan PT. Bank BNI syariah berada pada peringkat 2 yaitu Sehat dengan nilai keseluruhan 83,33\%. Dalam hal ini PT. Bank BNI syariah mampu menghadapi pengaruh negatif yang signifikan dari perubahan kondisi bisnis dan faktor eksternal lainnya. Dan juga PT. Bank BNI syariah mampu menjaga stabilitas kesehatan bank syariah di tahun 2016 (Jaelani, Sucipto, and Jalaludin 2020). Hal ini dibuktikan dengan penilaian kesehatan PT. Bank BNI syariah di triwulan pertama dan kedua tahun 2016 dengan peringkat Sangat Sehat. Dari hasil dari penilaian kesehatan dengan menggunakan metode RGEC ini juga dapat dijadikan acuan untuk evaluasi, saran perbaikan dan menjaga stabilitas kesehatan bank syariah.

Perbedaan penelitian saat ini dengan penelitian terdahulu dapat kita lihat dari tahun yang dilteliti, penelitian terdahulu hanya menganalisis laporan keungan dengan kurun waktu satu tahun, sedangkan penelitian saat ini mengalisis laporan keuangan dengan 
kurun waktu 5 tahun, selain itu tempat penelitianna yang digunakanpun berbeda.

\section{Analisis Tingkat Kesehatan Bank Mega,}

Tbk (Esomar 2020)

Penelitian ini bertujuan untuk mengetahui tingkat kesehatan pada PT. Bank Mega, Tbk selama tahun 2014-2017 dengan menggunakan metode RGEC. Metode RGEC merupakan salah satu alat analisis yang memudahkan dalam menilai tingkat kesehatan bank karena memberikan penilian yang terbuka terhadap faktor-faktor penting dalam usaha perbankan. Faktor-faktor yang dianggap penting tersebut diantaranya adalah : Penilaian profil resiko (Risk Profile), Penilaian Good Corporate Governance (GC), Penilaian rentabilitas (Earning) dan penilaian permodalan (Capital).

Penelitian ini menggunakan data sekunder. Data sekunder yang digunakan yaitu laporan keuangan yang dipublikasikan pada tahun 2014-2017. Dari data laporan keuangan tersebut kemudian dihitung rasio-rasio yang berkaitan dengan faktor-faktor yang dipertimbangkan dalam metode RGEC. Hasil dari rasio-rasio tersebut kemudian dipergunakan dalam penilaian tingkat kesehatan bank atau diteliti guna memperoleh predikat atau rating di mata bank indonesia, yaitu sangat sehat, sehat, cukup sehat, kurang sehat, atau tidak sehat.

Hasil dari penelitian yang dilakukan ini didapatkan bahwa dengan Metode RGEC PT Bank Mega, Tbk berada dalam kriteria sehat.

Lembaga penelitian saat ini dengan penelitian terdahulu sama yaitu pada Bank Mega Syariah akan tetapi tahun yang ditelitinya berbeda, pada penelitian saat ini peneliti menganilisi laporan keuangan dari tahun 2016-2019 sedangkan penelitian terdahulu peneliti menganalisis laporan keuangan pada tahun 2014-2017.
E. Analisis Penilaian Tingkat Kesehatan Bank Syariah Berdasarkan Metode RGEC Tahun 2012-2016 (Khudori 2018)

Tujuan dari penelitian ini adalah untuk mengetahui tingkat kesehatan perbankan syariah di Indonesia dengan menggunakan RGEC (Risk Profile, Good Corporate Governance, Earnings, dan Capital) pada periode 2012 - 2016. Metode penelitian yang digunakan meliputi metode kuantitatif dan kualitatif. Pada metode kuantitatif menggambarkan Profil Risiko dengan menggunakan rasio keuangan NPF (Non Performing Financing), dan FDR (Financing the Deposit Ratio), menggunakan rasio Laba ROA (return on asset), ROE (return on equity), BOPO (Cost to Income Ratio), dan CAR yang digunakan (Capital Adequacy Ratio). Pada metode kualitatif menjelaskan tentang Tata Kelola Perusahaan yang Baik. Jenis data yang digunakan adalah data sekunder berupa laporan tahunan dan laporan publikasi yang dipublikasikan di website yang dikelola per perbankan syariah di Indonesia. Hasil penelitian menunjukkan bahwa terdapat beberapa kondisi kesehatan pada perbankan syariah dengan kategori sangat sehat yaitu Bank Panin Syariah, kategori sehat yaitu Bank BCA Syariah, Bank BNI Syariah, Bank BRI Syariah, Bank Bukopin, Bank Mandiri Syariah, Bank Mega Syariah. , Bank Muamalat Syariah, dan Victoria Bank Syariah. Kategori kurang sehat adalah MayBank Syariah.

Perbedaan penelitian saat ini dengan penelitian terdahulu dapat kita lihat dari tahun penelitiannya, tempat penelitiaannya dimana penelitian saat ini hanya terfokus pada satu tempat lembaga perbankan syariah sedangkan penelitian terdahulu melakukan penelitian pada beberapa bank syariah yang ada di Indonesia.

F. Metode RGEC : Penilaian Tingkat Kesehatan Bank Pada Perusahaan 
Perbankan Syariah (Wahasusmiah and Watie 2019)

Penelitian ini bertujuan untuk mengetahui tingkat kesehatan Bank Umum Syariah menggunakan metode pengukuran yang diatur dalam Peraturan Bank Indonesia PBI No.13 / 1 / PBI / 2011, tentang Penilaian Tingkat Kesehatan Bank dengan metode RGEC. Faktor penilaian dalam metode RGEC adalah faktor risk profile (risiko bank), faktor Good Coorporate Governance (GCG), faktor earnings (rentabilitas) dan faktor capital (permodalan). Objek penelitian ini adalah semua perusahaan perbankan syariah yang terdaftar di Bursa Efek Indonesia pada periode 2014 sampai 2016. Teknik pengambilan sampel dalam penelitian ini menggunakan purposive sampling. Teknik analisis dalam penelitian ini adalah deskriptif kuatitatif dengan menghitung rasio keuangan menggunakan metode RGEC.Hasil penelitian ini menunjukkan bahwa bank yang memiliki tingkat kesehatan yang sehat dalam kategori sangat sehat untuk periode 2014 hingga 2016 adalah Bank Syariah Mandiri, BRI Syariah, BCA Syariah dan BNI Syariah, Bank Bukopin Syariah.

Perbedaan penelitian terdahulu dengan penelitian saat ini dapat kita lihat dari tahun yang diteliti, lalu lembaga keuangan syariah dan Teknik pengambilan sampel.

G. Perbandingan Tingkat Kesehatan Bank Umum Konvensional Dengan Bank Umum Syariah Di Indonesia Periode 2017-2018 Menggunakan Metode RGEC (Manajemen et al. 2021)

Penelitian ini merupakan deskriptif dan komparatif dengan Populasinya berjumlah 128 bank yang terdaftar di bursa efek indonesia. Sampel dalam penelitian ini sebanyak 40 bank konvensional dan bank syariah selama periode 2017-2018. Teknik pengambilan sampel menggunakan Purposive
Sampling dengan perolehan datanya adalah data sekunder, (data laporan keuangan, laporan keuangan tahunan dan laporan tata kelola perusahaan). Variabel yang dikaji adalah tingkat kesehatan bank dengan menggunakan teknik analisis diskriminan. Hasil penelitian menjelaskan perhitungan ratio NPL pada tingkat kesehatan bank konvensional lebih tinggi dibandingakn bank umum syariah, perhitungan ratio LDR pada tingkat kesehatan bank umum syariah lebih tinggi dibandingkan bank konvensional, perhitungan ratio ROA pada tingkat kesehatan menjelaskan tingkat kesehatan pada bank konvensional lebih baik dibandingkan bank umum syariah, perhitungan tingkat kesehatan bank menggunakan ratio ROE terlihat bahwa tingkat kesehatan pada bank konvensional lebih tinggi dibandingkat bank umum syariah yang terbilang rendah, perhitungan tingkat kesehatan mengunakan ratio BOPO menjelaskan bank konvensional dan bank umum syariah tergolong sama-sama memiliki tingkat kesehatan yang baik, dan perhitungan tingkat kesehatan menggunakan ratio CAR terlihat bahwa tingkat kesehatan pada bank umum syariah lebih baik dibandingkan bank konvesional. Perbandingan tingkat kesehatan bank konvensional dan bank umum syariah memiliki tingkat kesehatan berbeda-beda melalui perhitungan RGEC.

Perbadaan penelitian terdahulu dengan penelitian saat ini dapat kita lihat dari tahun laporan keuangan yang diteliti, lokasi penelitian, lalu metode penelitian yang dilakukanpun berbeda, pada penelitian terdahulu metode yang digunakan yaitu deskripsi dan komparasi sedangkan pada penelitian saat ini menggunakan deskriptip dengan data kuantitatif, serta yang membedakan dari penelitian terdahulu dan saat ini dilihat dari variabel yang digunakan. 
H. Analisis Penggunaan Metode Risk Profile, Good Corporate Governance, Earning, And Capital (RGEC) Dalam Mengukur Kesehatan Bank Pada Bank Umum Syariah Di Indonesia Periode 2012-2014 (Khalil and Fuadi 2016)

Penelitian ini menggunakan metode RGEC yang merupakan inovasi dari metode Capital, Asset, Management, Earning, Liquidity and Sensitivity to Market Risk (CAMELS) untuk menganalisis dan mengukur kesehatan bank dengan menggunakan perhitungan composite rank pada laporan keuangan. Jumlah bank syariah dalam penelitian ini adalah 11 bank, yaitu Bank Syariah Mandiri, BNI Syariah, Bank Muamalat Syariah, Bank Mega Syariah, BRI Syariah, BCA Syariah, Bank Syariah Bukopin, Bank BJB Syariah, Bank Panin Syariah, Bank Maybank Syariah dan Bank Victoria Syariah.

Hasil penelitian selama periode 2012-2014 menunjukkan bahwa bank dengan predikat tersehat pada tahun 2012 adalah Bank Muamalat Syariah, dan pada tahun 2013 adalah Bank BNI Syariah dan Bank Mega Syariah pada tahun 2013 serta pada tahun 2014 adalah Bank Bank Panin Syariah dan Bank BNI Syariah.

Perbedaan penelitian terdahulu dengan penelitian saat ini dapat kita lihat dari tahun yang diteliti,penelitian terdahulu hanya meneliti laporan keuangan selama 2 tahun dari tahun 2012-2014 sedangkan penelitian saat ini menganalisis laporan keuangan selama 5 tahun dari tahun 2016-2019, selain itu lokasi penelitianpun berbeda, pada penelirian terdahulu peneliti melakukan penelitian pada 11 bank syariah di Indonesia sedangkan pada penelitian saat ini hanya 1 bank syariah.

I. Analisis Kinerja Keuangan Dengan Pendekatan Metode RGEC Pada Bank BUMN Periode 2012-2013 (Mandasari 2015)
Tujuan penelitian ini untuk menganalisis kinerja keuangan Bank BUMN (BNI, BRI, BTN dan Bank Mandiri) periode 2012-2013 dengan pendekatan metode RGEC (Risk Profile, Good Corporate Governance, Earnings, Capital).Alat analisis yang dipergunakan adalah Metode RGEC (Risk Profiel, GCG, Earning, Capital). Sedangkan Metode penelitian ini menggunakan deskriptif dengan pendekatan kuantitatif. Populasi penelitian ini seluruh Bank BUMN yang terdaftar dalam direktori Bank Indonesia, yang memiliki laporan tahunan periode tahun 2012 sampai 2013. Teknik pengumpulan data yang dipergunakan adalah teknik dokumentasi dan teknik kepustakaan.Hasil penelitian menunjukkan secara keseluruhan kinerja keuangan Bank BUMN selama periode 2012-2013 dari segi profil risiko yaitu dengan menganalisis risiko kredit yang diwakili dengan rasio NPL dikatakan baik dan dari analisis risiko likuiditas yang diwakili dengan rasio LDR dapat dikatakan Cukup Likuid. Sedangkan dari segi Good Corporate Governance (GCG) kinerja bank Sangat Baik. Serta secara keseluruhan kinerja keuangan dari segi Rentabilitas (Earning) yaitu dengan menganalisis rasio ROA atau perolehan laba berdasarkan aset dan Rasio NIM atau kemampuan manajemen dalam mengendalikan biaya-biaya Bank dikatakan Baik. Dan secara keseluruhan kinerja keuangan dari segi permodalan dengan menganalisis perbandingan rasio modal terhadap aktiva tertimbang menurut risiko (ATMR) yang diwakili dengan menghitung rasio CAR (Capital Adequacy Ratio) Bank dikatakan Baik.

Perbedaan penelitian terdahulu dengan penelitian saat ini dapat kita lihat dari tahun yang diteliti, penelitian terdahulu hanya meneliti laporan keuangan selama 1 tahun dari tahun 2012-2013 sedangkan penelitian saat ini menganalisis laporan keuangan selama 5 
tahun dari tahun 2016-2019, selain itu lokasi penelitianpun berbeda, pada penelitian terdahulu peneliti melakukan penelitian pada Bank syariah milik Negara, sedangkan pada penelitian saat ini hanya 1 bank syariah bukan milik negara. Serta variabel yang digunakan oleh penelitian terdahulu dengan saat ini berbeda.

\section{METODOLOGI PENELITIAN}

Penelitian ini menggunakan pendekatan penelitian deskriptif dengan jenis data kuantitaif, menggunakan variabel tunggal yaitu tingkat keseahatn bank. Model penelitian yang menggambarkan dan menginrpretasikan objek sesuai dengan yang terjadi. Penelitian ini dilakukan dengan mengumpulkan data-data dengan ketentuan yang telah di atur oleh Bank Indonesia. Sumber data yang digunakan yaitu data sekuner dari web resmi www.megasyariah.co.id periode 2016-2019.

\section{HASIL DAN PEMBAHASAN}

A. Hasil

Hasil penilaian tingkat kesehatan PT. Bank Mega Syariah Tbk menggunakan metode Risk Profile, Good Corporate Governance, Earnings dan Capital (RGEC) periode 20162019 disajikan sebagai berikut.

Tabel 7 Penetapan PK PT. Bank Mega Syariah Tbk Periode 2016-2019

\begin{tabular}{|c|c|c|c|c|c|c|c|c|c|c|c|}
\hline \multirow{2}{*}{ Tahun } & \multirow{2}{*}{ Indikator } & \multirow{2}{*}{ Rasio } & \multirow{2}{*}{ Nilai } & \multicolumn{5}{|c|}{ Kriteria } & \multirow{2}{*}{ Predikat } & \multirow{2}{*}{ Ket } & \multirow{2}{*}{ PK } \\
\hline & & & & 1 & 2 & 3 & 4 & 5 & & & \\
\hline \multirow{7}{*}{2016} & \multirow[b]{2}{*}{ Risk Profile } & NPF & $3,30 \%$ & & $\checkmark$ & & & & Sehat & Sehat & \multirow{7}{*}{ Sehat } \\
\hline & & FDR & $\begin{array}{c}95,24 \\
\%\end{array}$ & & & $\checkmark$ & & & $\begin{array}{l}\text { Cukup } \\
\text { Sehat }\end{array}$ & $\begin{array}{l}\text { Cukup } \\
\text { Sehat }\end{array}$ & \\
\hline & $\begin{array}{c}\text { Good } \\
\text { Corporate } \\
\text { Governance }\end{array}$ & GCG & 2 & & $\checkmark$ & & & & Sehat & Sehat & \\
\hline & \multirow{2}{*}{ Earnings } & ROA & $2,63 \%$ & $\checkmark$ & & & & & $\begin{array}{l}\text { Sangat } \\
\text { Sehat }\end{array}$ & $\begin{array}{l}\text { Sangat } \\
\text { Sehat }\end{array}$ & \\
\hline & & NIM & $7,56 \%$ & $\checkmark$ & & & & & $\begin{array}{c}\text { Sangat } \\
\text { Sehat }\end{array}$ & $\begin{array}{c}\text { Sangat } \\
\text { Sehat }\end{array}$ & \\
\hline & Capital & CAR & $\begin{array}{c}23,53 \\
\%\end{array}$ & $\checkmark$ & & & & & $\begin{array}{l}\text { Sangat } \\
\text { Sehat }\end{array}$ & $\begin{array}{l}\text { Sangat } \\
\text { Sehat }\end{array}$ & \\
\hline & \multicolumn{2}{|c|}{ Nilai Komposit } & 30 & 15 & 8 & 3 & $\mathbf{0}$ & $\mathbf{0}$ & \multicolumn{2}{|c|}{$\begin{array}{c}(26 / 30) * 100 \%= \\
86,7 \%\end{array}$} & \\
\hline \multirow{5}{*}{2017} & \multirow[b]{2}{*}{ Risk Profile } & NPF & $2,93 \%$ & & $\checkmark$ & & & & Sehat & Sehat & \multirow{5}{*}{ Sehat } \\
\hline & & FDR & $\begin{array}{c}91,05 \\
\%\end{array}$ & & & $\checkmark$ & & & $\begin{array}{l}\text { Cukup } \\
\text { Sehat }\end{array}$ & $\begin{array}{l}\text { Cukup } \\
\text { Sehat }\end{array}$ & \\
\hline & $\begin{array}{c}\text { Good } \\
\text { Corporate } \\
\text { Governance }\end{array}$ & GCG & 2 & & $\checkmark$ & & & & Sehat & Sehat & \\
\hline & \multirow{2}{*}{ Earnings } & ROA & $1,56 \%$ & $\checkmark$ & & & & & $\begin{array}{l}\text { Sangat } \\
\text { Sehat }\end{array}$ & $\begin{array}{l}\text { Sangat } \\
\text { Sehat }\end{array}$ & \\
\hline & & NIM & $6,03 \%$ & $\checkmark$ & & & & & $\begin{array}{l}\text { Sangat } \\
\text { Sehat }\end{array}$ & $\begin{array}{c}\text { Sangat } \\
\text { Sehat }\end{array}$ & \\
\hline
\end{tabular}

EKSISBANK (Ekonomi Syariah dan Bisnis Perbankan), Volume 5, Nomor 1, Juni 2021 http://journal.sties-purwakarta.ac.id/index.php/EKSISBANK/ 


\begin{tabular}{|c|c|c|c|c|c|c|c|c|c|c|c|}
\hline \multirow{4}{*}{ Tahun } & \multirow{2}{*}{ Indikator } & \multirow{2}{*}{ Rasio } & \multirow{2}{*}{ Nilai } & \multicolumn{5}{|c|}{ Kriteria } & \multirow{2}{*}{ Predikat } & \multirow{2}{*}{ Ket } & \multirow{2}{*}{ PK } \\
\hline & & & & 1 & 2 & 3 & 4 & 5 & & & \\
\hline & Capital & CAR & 22,19 & $\checkmark$ & & & & & $\begin{array}{l}\text { Sangat } \\
\text { Sehat }\end{array}$ & $\begin{array}{c}\text { Sangat } \\
\text { Sehat }\end{array}$ & \\
\hline & \multicolumn{2}{|c|}{ Nilai Komposit } & 30 & 15 & 8 & 3 & $\mathbf{0}$ & $\mathbf{0}$ & \multicolumn{2}{|c|}{$\begin{array}{c}(26 / 30) * 100 \%= \\
86,7 \%\end{array}$} & \\
\hline \multirow{7}{*}{2018} & \multirow[b]{2}{*}{ Risk Profile } & NPF & $1,72 \%$ & $\checkmark$ & & & & & Sehat & Sehat & \multirow{7}{*}{ Sehat } \\
\hline & & FDR & $\begin{array}{c}94,53 \\
\%\end{array}$ & & & $\checkmark$ & & & $\begin{array}{l}\text { Cukup } \\
\text { Sehat }\end{array}$ & $\begin{array}{l}\text { Cukup } \\
\text { Sehat }\end{array}$ & \\
\hline & $\begin{array}{c}\text { Good } \\
\text { Corporate } \\
\text { Governance }\end{array}$ & GCG & 1 & $\checkmark$ & & & & & Sehat & Sehat & \\
\hline & \multirow{2}{*}{ Earnings } & ROA & $0,89 \%$ & & & $\checkmark$ & & & $\begin{array}{l}\text { Sangat } \\
\text { Sehat }\end{array}$ & $\begin{array}{c}\text { Sangat } \\
\text { Sehat }\end{array}$ & \\
\hline & & NIM & $5,36 \%$ & $\checkmark$ & & & & & $\begin{array}{l}\text { Sangat } \\
\text { Sehat }\end{array}$ & $\begin{array}{c}\text { Sangat } \\
\text { Sehat }\end{array}$ & \\
\hline & Capital & CAR & $\begin{array}{c}19,96 \\
\%\end{array}$ & $\checkmark$ & & & & & $\begin{array}{l}\text { Sangat } \\
\text { Sehat }\end{array}$ & $\begin{array}{l}\text { Sangat } \\
\text { Sehat }\end{array}$ & \\
\hline & \multicolumn{2}{|c|}{ Nilai Komposit } & 30 & 20 & $\mathbf{0}$ & 6 & $\mathbf{0}$ & $\mathbf{0}$ & \multicolumn{2}{|c|}{$\begin{array}{c}(26 / 30) * 100 \%= \\
86,7 \%\end{array}$} & \\
\hline 2019 & Risk Profile & $\mathrm{NPF}$ & $2,15 \%$ & $\checkmark$ & & & & & Sehat & Sehat & \\
\hline
\end{tabular}

\section{B. Pembahasan}

\section{Risk Profile}

Dalam penelitian ini menganalisis aspek risiko kredit yang menggunakan NPF dan riisko likuiditas menggunakan LDR. Nilai rasio NPF mulai dari tahun 2016 hingga 2019 masing-masing sebesar 3,3\% 2,95\% 1,72\% $2,15 \%$. Dari data ini menggambarkan bank mampu mengelola dan menjaga tingkat kualitas kredit dalam kurun waktu empat tahun dan termasuk dalam kategori sehat.

Selanjutnya untuk nilai rasio FDR mulai dari tahun 2016 hingga 2019 ialah 95,24\% 91,05\% 94,53\% 90,88\%. Data tersebut memperlihatkan bahwa bank mempunyai kemampuan cukup baik dalam mengembalikan dana kepada deposan dengan mengandalkan kredit yang diberikan sebagai sumber likuiditasnya.

\section{Good Corporate Governance}

Dalam konteks ini penilaian dilakukan sendiri oleh PT. Bank Mega Syariah Tbk atau bisa disebut dengan self assessment. Penilaian ini mengenai tata kelola perusahaan sesuai dengan ketentuan berlaku. Nilai komposit GCG yang diperoleh pada tahun 2016, 2017 dan 2019 berada pada nilai komposit 2 yang berarti sehat. Sedangkan pada tahun 2019 nilai komposit bernilai 1 yang berarti sangat sehat.

\section{Earnings (Rentabilitas)}


Penilaian pada faktor ini menggunakan rasio ROA dan NIM. Untuk nilai ROA dalam kurun waktu empat tahun masing-masing sebesar 2,63\% $\quad 1,56 \% \quad 0,89 \% \quad 0,93 \%$. Data tersebut menggambarkan bahwa kemampuan bank dalam memperoleh laba dengan menggunakan asetnya berjalan dengan baik. Hanya pada tahun 2016 tidak berjalan dengan baik. Dari keseluruhan data ROA termasuk dalam kategori sehat.

Untuk nilai rasio NIM mulai dari tahun 2016 hingga 2019 masing-masing sebesar $7,56 \%$ 6,03\% 5,36\% dan 5,52\%. Data tersebut memperlihatkan bahwa kemampuan bank dalam memperoleh pendapatan dari bunga termasuk dalam kategori sangat sehat. Hal ini sesuai dengan komposit NIM bahwa jika mencapai > 3 maka termasuk dalam kategori sangat sehat.

\section{Capital (Modal)}

Penilaian tingkat kesehatan bank dalam inidkator ini menggunakan rasio CAR. Nilai CAR dalam kurun waktu empat tahun ini ialah $23,53 \%$ 22,19\% 19,96\% dan 50,54\%. Data tersebut menunjukkan bahwa bank mampu menyangga jika terjadi kerugian operasional dan dapat mendukung pemberian kredit yang besar. Karena jika nilai CAR lebih dar $8 \%$ maka termasuk dalam kategori sangat sehat.

Berdasarkan pada tabel yang telah di sajikan tingkat kesehatan PT. Bank Mega Syariah Tbk dengan menggunakan metode RGEC periode 2016-2019 menunjukan kinerja pada peringkat komposit 2 (PK-2) mempunyai arti bawah dalam kondisi sehat. Meskipun ada beberapa rasio yang termasuk dalam kategori kurang baik, namun pihak manajemen dalam kurun waktu empat tahun ini dapat mempertahankan kondisi kesehatan bank.

\section{KESIMPULAN}

Dari keseluruhan hasil analisis dengan menggunakan metode RGEC pada PT. Bank Mega Syariah Tbk periode 2016-2019 bank termasuk dalam komposit 2 yaitu termasuk pada kategori sehat. Di analisis dengan menggunakan faktor Risk Profile, Good Corporate Governance, Earning dan Capital, dengan rincian sebagai berikut: 1) Risk Profile: Nilai rasio FDR mulai dari tahun 2016 hingga 2019 ialah 95,24\% 91,05\% 94,53\% 90,88. Nilai rasio NPF mulai dari tahun 2016 hingga 2019 masing-masing sebesar 3,3\% 2,95\% $1,72 \% \quad 2,15 \%$; 2) Good Corporate Govermence: Nilai komposit GCG yang diperoleh pada tahun 2016, 2017 dan 2019 berada pada nilai komposit 2 yang berarti sehat. Sedangkan pada tahun 2019 nilai komposit bernilai 1 yang berarti sangat sehat. 3) Earning: Nilai ROA dalam kurun waktu empat tahun masing-masing sebesar 2,63\% $1,56 \% 0,89 \% 0,93 \%$. Nilai rasio NIM mulai dari tahun 2016 hingga 2019 masing-masing sebesar $7,56 \% 6,03 \% 5,36 \%$ dan $5,52 \%$. 4) Capital: Nilai CAR dalam kurun waktu empat tahun ini ialah 23,53\% 22,19\% 19,96\% dan $50,54 \%$. Implikasinya pihak manajemen bank tetap harus dapat mempertahankan tingkat kesehatan, karena kesehatan bank menjadi hal paling utama dan menjadi landasan dalam kepercayaan para deposan untuk mengelola dananya.

\section{DAFTAR PUSTAKA}

Christian, F. J., Tommy, P., \& Tulung, J. (2017). Analisa Kesehatan Bank Dengan Menggunakan Metode RGEC pada Bank BRI dan Mandiri Periode 2012-2015. Jurnal EMBA, 5(2), 530-540.

Darmawi, H. (2011). Manajemen Perbankan. PT Bumi Aksara.

Dewi, G., \& Triaryati, N. (2017). Pengaruh Faktor Internal Dan Eksternal Bank Terhadap Net Interest Margin Di Indonesia. E-Jurnal Manajemen Universitas Udayana, 6(6), 252811.

Fitriano, Y., \& Sofyan, R. M. (2019). Analisis Tingkat Kesehatan Bank Dengan Penerapan Metode Rgec (Risk Profile, Good Corporate Governance, Earnings Dan Capital) Pada

EKSISBANK (Ekonomi Syariah dan Bisnis Perbankan), Volume 5, Nomor 1, Juni 2021 
Pt.Bank Bengkulu. Managament Insight: Jurnal Ilmiah Manajemen, 13(1), 73-91. https://doi.org/10.33369/insight.14.1.73-91

Kaihatu, T. S. (2006). Good Corporate Governance dan Penerapannya di Indonesia. Jurnal Ekonomi Manajemen, 8(1), 1-9.

Kasmir. (2016). Bank dan Lembaga Keuangan Lainnya. Rajawali Press.

Marimin, A., \& Romdhoni, A. H. (2017). Perkembangan Bank Syariah Di Indonesia. Jurnal Ilmiah Ekonomi Islam, 1(02), 75-87. https://doi.org/10.29040/jiei.v1i02.30

Paramartha, I. M., \& Darmayanti, N. P. A. (2017). PENILAIAN TINGKAT KESEHATAN BANK DENGAN METODE RGEC PADA PT. BANK MANDIRI (PERSERO), Tbk. E-Jurnal Manajemen Unud, 6(2), 948-974.

Prastyananta, F., Saifi, M., \& NP, M. (2016). ANALISIS PENGGUNAAN METODE RGEC (RISK PROFILE, GOOD CORPORATE GOVERNANCE, EARNING, CAPITAL) UNTUK MENGETAHUI TINGKAT KESEHATAN BANK (Studi Pada Bank Umum Yang Terdaftar Di BEI Periode 2012-2014). Jurnal Administrasi Bisnis S1 Universitas Brawijaya, 35(2), 68-76.

Rahmani, N. A. B. (2017). Analisis Pengaruh Capital Adequacy Ratio (CAR) dan Financing to Deposit Ratio (FDR) terhadap Return On Asset (ROA) dan Return On Equity (ROE) Pada Perusahaan Bank Umum Syariah di Indonesia. Human Falah, 4(2), 299-316.

Rivai, V. (2007). Bank adn Financial Institute Management. PT Raja Grafindo.

Romdhoni, A. H. (2016). Analisis Likuiditas Berbasis Laporan Keuangan Bri Syariah Tahun 2013 - 2015. Jurnal Ilmiah Ekonomi Islam, 2(02), 1-10. https://doi.org/10.29040/jiei.v2i02.46

Sutrisno. (2003). Manajemen Keuangan. Ekonisia.

Wahasusmiah, R., \& Watie, K. R. (2019). Metode Rgec: Penilaian Tingkat Kesehatan Bank Pada Perusahaan Perbankan Syariah. IFinance: A Research Journal on Islamic Finance, $\quad 4(2), \quad$ 170-184. https://doi.org/10.19109/ifinance.v4i2.3038 Wahyu, D. R. (2016). FINANCING TO DEPOSIT RATIO (FDR) SEBAGAI SALAH SATU PENILAIAN KESEHATAN BANK UMUM SYARIAH (Study Kasus Pada Bank BJB Syariah Cabang Serang). ISLAMICONOMIC: Jurnal Ekonomi Islam, 7(1), 19-36. https://doi.org/10.32678/ijei.v7i1.34

EKSISBANK (Ekonomi Syariah dan Bisnis Perbankan), Volume 5, Nomor 1, Juni 2021 http://journal.sties-purwakarta.ac.id/index.php/EKSISBANK/ 